AUTHOR(S): Thomas E. Sampson, Sin-Tao Hsue, Jack L. Parker, Sue S. Johnson, and D. F. Bowersox

\title{
SUBMITTED TO:
}

To be presented at the Fifth Symposium: $X$ - and Gamma Rays in Ann Arbor, Michigan on June 10-12, 1981. yoses 


\title{
THE DETERMINATION GF PLUTON IUM ISOTOPIC COMPOSITION BY GAMMA-RAY SPECTROSCOPY
}

by

T. E. Sampson, S.-T. Hsue, J. L. Parker, S. S. Johnson, and D. F. Bowersox

\begin{abstract}
We discuss the genera? approach, computerized data analys is methods, arid results of measurements used to determine the isotopic composition of plutonium by gamma-ray spectroscopy. The simple techniques are designed to be applicable to samples of arbitrary size, geometry, age, chemical, and isotopic composition. The conllination of the qamma spectroscopic medsurement of isotopic composition coupled with calorimetric measurement of total sample poiwer is shown to give a totally nordestructive determination of sample piutconium mass with a precision of $0.6^{\prime \prime}$ for 1000-g samples of $\mathrm{PuO}_{2}$ with 12 " ${ }^{240} \mathrm{pu}_{\mathrm{u}}$ rontent. The precision of iscotopic measurements depends upon many factors, including sample size, sample geometry, and isotopic content.

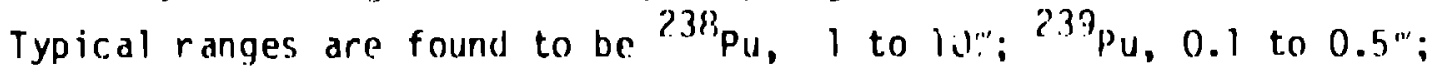
240) $\mathrm{Pu}$, ? to 5."; ${ }^{241} \mathrm{Pu}, 0.3$ to $0.7 \%$ : ${ }^{242} \mathrm{Pu}$ (determined by isotopic correlacion); and $21 \mathrm{Nn}, 0.2$ to $10^{\prime \prime}$.
\end{abstract}

\section{INTRODUI:TION}

Work at. the 'os Alairses National laboratory in the area of plutonitum iro. topic: andlys is by calluna-rily spectroscopy starterl tn 1974 when J. I. Palker and

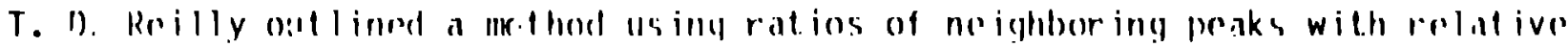


efficiency corrections determined irom the spectrum under study. ${ }^{1}$ These techniques, using garmma rays in the 120 to 420-keV range, have received wide acceptance and have been put into routine use at several laboratories. 2,3 Results from an interlaboratory comparison have been published. ${ }^{4}$ Different latoratories generally use the same techniques with the main difference being the methcds used for determining photopeak areas.

A somewhat different approach has been used by Gunnink ${ }^{5}$ who fits the complex $100-\mathrm{keV}$ region with response functior.s of each isotope. This method has been used very successfully for dilute solutions, where attenuation currections are small.

Gunnink and coworkers, ${ }^{6,7}$ and Cowder et al., 8 have used gamma rays in the fo-keV region for isotopic analys is on freshly separated solutions in the 100 to $300-g / \&$ range. Use of gamma rays in the $60-\mathrm{keV}$ region has a'so been discussed by Umezawa $\in t$ al. 9

Techniques similar to those of Ref. 1 have been described by Dragnev and co-workels, ${ }^{10-12}$ and Reilly et al. 13

The work reported here vill enable routine application of this method for verification of plutonium isotopic composition and for determination of plutonium isotopic composition, which is necessary for proper interpretation of total plutonium measurements obtained by cislorimetry or neutron coincidence counting.

The vrocedures to be described require no peak fitting thus minimizing computer core and speed requirements. Little training is needed for the method to be routinely used by technicians. The method represents a simple, and perhaps th- most versatile, single detector approach to plutonium isotopics.

\section{GTNTRAL APPROACH}

The philosophy that has qoverned this approach is one of sinplicily. The approach uses the simplest data acquisition and analys is techniques and yet has the widest applicability to arbitrary sample configurations.

The atom ratio of isotopes 1 and $?$ is determined from a gamma-ray spectrum by mearls of 


$$
\frac{N_{1}}{N_{2}}=\frac{C_{1}}{C_{2}} \times \frac{T_{1 / 2}(1)}{T_{1 / 2}(2)} \times \frac{B_{2}}{B_{1}} \times \frac{R_{2}}{R E_{1}}
$$

where

$N=$ number of atoms of the indicated isotope

$C=$ photopeak counts from selected gamma ray from the indicated isotope

$T_{1 / 2}=$ half-life of the indicted isotope

$B=$ branching ratio of the selected gamma $r$ ay from the indi ated isotope

$\mathrm{RE}$ = relative efficiency at the selected gammia-ray energy, including gtometry, sample self-absorption, attenuation, and detector efficiency.

The isotupic ratios are measured using gamma rays in the 120 to $420-\mathrm{keV}$ range. Half-lives and branching ratios are taken from the iiterature. ${ }^{14,15}$ The relative efficiency is determined from the spectrum urier study by determining the quotient of the photopeak counts and t.te branching ratio for a series of gamma rays from one of the isotopes in the sample. ${ }^{239} \mathrm{Pu}$, $241_{\mathrm{Pu}}$, and $241_{\mathrm{Pu}} 237 \mathrm{ll}$ gamma rays are used in this method with the $241_{\mathrm{pu}}$ and $241_{\mathrm{p}_{u-}} 237 \mathrm{U}$ relative efficiency points being normalized to thuse from ${ }^{239} \mathrm{Pu}$.

Photopeak areas are determined by region of interest (ROI) jummation. 16 Background regions are selected ahove and below each photopeak. A linear background is interpolated under the photopeak from the centroids of the background reqions. Background reqions are carefully selectiad to avoid neighboring peak interferences, particularly frem ${ }^{241} \mathrm{Am}$ which can vary greatly from sample to sample.

Digital gain and zero stabilization is users in the data acquisition olec:tronics. This is important to ensure that the peaks don't wander out of their assigned R015. The 129.3-keV anr 413.7-kav $\mathrm{reak}$. of $234 \mathrm{pu}$ are used for zero and qain stahilization.

The ROI sumnation method puts greac emphas is on good deteclor resolulion in order to be able to resolve the peaks of interest from close-lying noighbors. A ligh-resolution (-hon eV at $127 \mathrm{keV}$ ) planar detector is used for these measurements. The techniques discussed here are applicable to a very 
wide range of sample types. Sample size is only limited by count-rate and counting time considerations and can range from $-0.1 \mathrm{~g}$ to as large as criticality considerations alloh. We attempt to keep count rates at about $10 \mathrm{kHz}$ as a compromise between optimal data collection rates and best resolution. Counting times are influenced by the statistical precision desired and the ultimate application of the isotopic results. Simple verifications of, say,

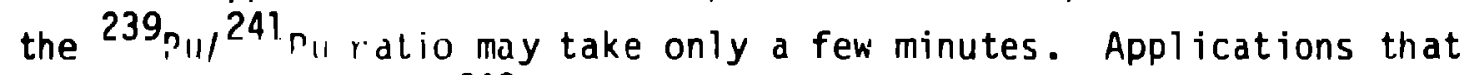
requir, iu and/or ${ }^{240} \mathrm{P}_{\mathcal{A}}$ isotopics generally require at least several hours.

Filters are used to reduce the count rate from ${ }^{241}$ Am at $59.5 \mathrm{keV}$ and the 100-keV $x-r a y$ and gamma-ray complex in order to remove any pile-up peaks from the 150- t.o 165-keV region.

A requirement for this method is that the isotopic distribution of all plutonium in the sample must be homogeneous. The sample itself may contain a nonhomoyeneous plutonium distribution, but all plutonium should have the same isotopic composition.

The methods utilized apply to both fresilly separated (no ${ }^{241} \mathrm{Pu}_{\mathrm{U}}{ }^{237} \mathrm{U}$ equilibrium) and aged ( $>45$ days from U separaiion) plutonium.

\section{ANALYSIS METHOD}

Relative efficiency values are calculated from the pea's areaibrancining ratio for $239 \mathrm{pu}$ lines at 179.3, 143.4 + 144.?, 171.3, 179.̈, 189.3, 195.7, $203.5,255.4,297.5,345.0,375.0$, and $413.7 \mathrm{keV}$. All relitive efficiencies are normalized to a value of 1.0 at $413.7 \mathrm{keV}$.

Next, the ${ }^{239} \mathrm{Pu}$ relative efficiency values at 345.0 and $375.0 \mathrm{keV}$ ara linearly extrapolated to give values at 3.32 .4 and $335.4 \mathrm{keV}$. The peak com-

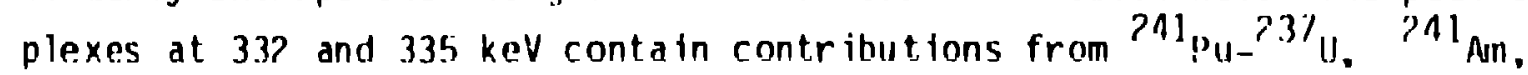
and ${ }^{239} \mathrm{Pu}$. The ${ }^{39} \mathrm{pu}$ component is subtracted from both complexes using the $345.0-k e V{ }^{239} p_{u} 1$ inc. The remaining peak areas at 333 and $235 \mathrm{keV}$

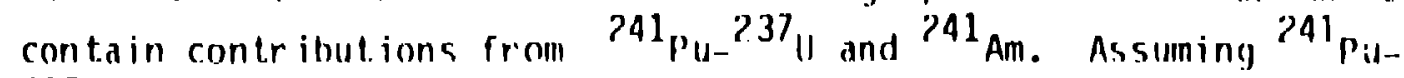
237 If equilibr ium, the (wo peak arcas and two isotopic unknowns are used to solve for the ${ }^{241} \mathrm{Am} /{ }^{241} \mathrm{Pu}$ ratio. ${ }^{1}$ This $24 \mathrm{Nm}^{2 \mathrm{Al}} \mathrm{Pu}$ ratio $\mathrm{l}$ " used to correct other $291_{\mathrm{Pu}-}{ }^{237} 11$ peaks at $164.6,203.0,267.5,33 \% .4$, 335.4 , 368.6 , and $370.4 \mathrm{keV}$ for the ir ${ }^{241} \mathrm{Am}$ content. ${ }^{1}$ The same procedure 
also applies to nonequilibrium samples, although in that case the ratio solved for is proportional to ${ }^{241} \mathrm{Am} /{ }^{237} \mathrm{U}$. The ${ }^{241} \mathrm{Am}$ correction formalisin

remains unchanged. The ${ }^{239} \mathrm{Pu}_{\mathrm{u}}$ relative efficiency points at $129.3,143.4+$ 144.2, 171.3, and $203.5 \mathrm{keV}$ are fit to a quadratic to determine the relative efficiency at $208 \mathrm{keV}$. Relative efficiency points at $148.6 \mathrm{keV}$ from ${ }^{24} \mathrm{l}_{\mathrm{ru}}$, and $164.6,208.0,267.5$, and 332.4 from ${ }^{24} \mathrm{I}_{\mathrm{Pu}-}{ }^{237} \mathrm{U}$ are normallzed to the values determined from ${ }^{239} \mathrm{Pu}$ lines by using a weighted avarage of normalization factors at 332.4 and $208.0 \mathrm{keV}$. The resulting relative efficiency curves for two sample sizes and a $200 \mathrm{~mm}^{?} \times 10 \mathrm{~mm}$ planar detector are showll in Fig. 1 .

In keeping with our goai of simplicity, we wo not attempt to fit the entire relative efficiency curve. Interpolation and extrapolation over limited ranges are sed to calculate the needed relative efficiency values.

For samples with ${ }^{24} \mathrm{l}_{\mathrm{Pu}-}{ }^{237} \mathrm{U}$ equilibrium, we calculate needed relaitive efficiencies as follows. Efficiencies at $152.7\left({ }^{238} \mathrm{Pu}\right), 160.3\left({ }^{240} \mathrm{Pu}\right)$, and $161.5 \mathrm{keV}\left({ }^{239} \mathrm{Pu}\right)$ are determined by 7 inear interpolation between 148.6 and $164.6 \mathrm{keV}$. The efficiency at $169.6 \mathrm{keV}\left({ }^{241} \mathrm{Am}\right)$ is set equal to that at 171.3. The efficicncy for ${ }^{24 \mathrm{l}} \mathrm{Am}$ at $12.5 .3 \mathrm{keV}$ is determined by linear extraoolation from 148.6 and $129.3 \mathrm{keV}$.

The isotopic razins ior equillhrium (aged) samples are calculated as fol-

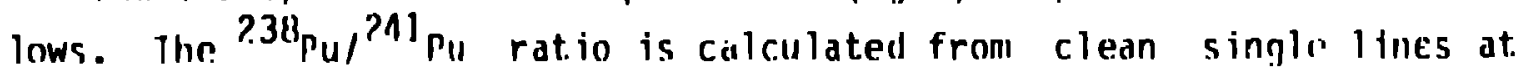
$15 \% .7 \mathrm{keV}\left({ }^{238} \mathrm{Pu}\right)$ and $198.6 \mathrm{keV}\left({ }^{24} \mathrm{Pu}\right)$.

Two values are ralculated for the ${ }^{239} \mathrm{pu} /{ }^{241} \mathrm{pu}$ ratio: first, from the

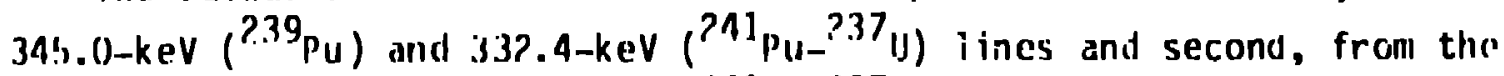
203.5-keV ( ${ }^{239} \mathrm{Pu}$ ) and $208.0-\mathrm{keV}\left({ }^{241} \mathrm{Pu}{ }^{237} \mathrm{U}\right)$ lines. The final value for Lhe ${ }^{239} \mathrm{Fu} /{ }^{211} \mathrm{Pu}$ ratio is determined from a weighted average of the two ratios. The 203/208 ration gives inore precise results for low burnup pu while the 34i/33\% ralio is belter for reactur grade Pu.

Thu PAOPu/PAL raliu is ralculiated trom the 160.3-keV (240Pu) and

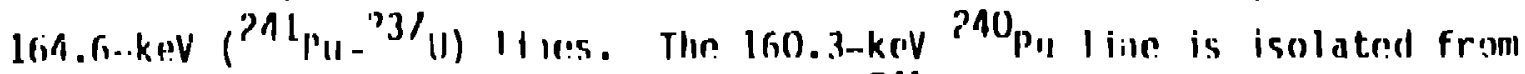
the 160-keV codu, lex by stripling out the 211 llu component at $260.0 \mathrm{heV}$ with

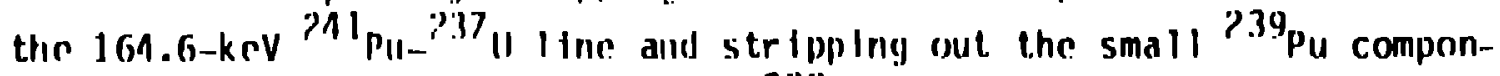
rnt at 160.7 kev with the 161.5-kev 239pu line. 
The ${ }^{241} \mathrm{Am} /{ }^{239} \mathrm{Pu}$ ratio is calculated two ways. The first uses the 125.3-keV ${ }^{241}$ AmI 1 ine and the $129.3-\mathrm{keV}{ }^{239} \mathrm{Pu} 1$ ine with ${ }^{239} \mathrm{Pu}$ interferences at 124.5 and $125.2 \mathrm{keV}$ being stripped using the 129.3-keV ${ }^{239} \mathrm{Pu} 1$ ine.

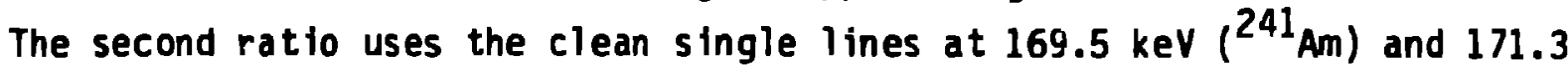
keV ( $\left.{ }^{239} \mathrm{Pu}\right)$. The latter ratio is not useful below ${ }^{241} \mathrm{Am}$ concentratiuns of about $1000 \mathrm{ppm}$ because the $169.5-\mathrm{keV}{ }^{241}$ Am line is not visible. The 125-keV/129-keV ratio can give ${ }^{241} \mathrm{Am} i{ }^{239} \mathrm{Pu}$ ratios down to a few hundred ppm americium concentrations. The final ${ }^{241} \mathrm{Am} /{ }^{239} \mathrm{Pu}$ ratio is calculated from a weighted average of the two ratios.

For freshly separated samples (no ${ }^{24} \mathrm{I}_{\mathrm{Pu}-}{ }^{237} \mathrm{U}$ equilibrium) all isotopic ratios are calculated with respect to the $148.6-\mathrm{keV}{ }^{241} \mathrm{Pu} 1$ ine. The relative efficiency at $148.6 \mathrm{keV}$ is found from a quadratic fit to the efficiency points at 129.3, 143.4 + 144.2, 164.6, 171.3, 203.5, and $208.0 \mathrm{keV}$. The ${ }^{238} \mathrm{Pu} 1 \mathrm{ine}$ at 152.7 , the ${ }^{239} \mathrm{Pu}$ line at 129.3 , and the $240 \mathrm{Pu}$ line at $160.3 \mathrm{keV}$ are used for the three isotopic ratios. The correction for the $160.0-\mathrm{keV}{ }^{241} \mathrm{Pu}$ line is made from the 148.6-keV line. ${ }^{241} \mathrm{Am}$ is determined as before. Comparing the relative efficie.ıcy at $148 \mathrm{keV}$ deterniried in this fashion with that found by assuming that the plutonium is aged enables one to determine if the sample is in $241_{\mathrm{Pu}}{ }^{237} \mathrm{U}$ equilibrium.

All ratios contain one or more adjustable constants (depending on the aigebraic form), which are adjusted using measurements with knoivn standards. These adjustable constants correct for several effects, One effect is possible errors in the branching ratios. ${ }^{4}$ Other effects con arise from systeriatic errors introduced hy the specific peak-area analys is ar.d the relative. efficiency interpolations and extrapolations used. rypically, adjustments are a few per cent.

The ratios of ${ }^{238} \mathrm{Pu}, 239 \mathrm{Pu}$, and ${ }^{240} \mathrm{Pu}$ to ${ }^{241} \mathrm{Pu}$ are converted to weight fractions of those isotopes. The ${ }^{2.7 ?} \mathrm{Pu}$ fraction is determined by isotopic correlation techniques. The plutonilum isotopic weight fractions are then recomputed incorporating the $24 ?^{7} \mathrm{Pu}$ 、alue. The ${ }^{241} \mathrm{Am}$ content is computed from the measured ${ }^{241} \mathrm{Am} /{ }^{239} \mathrm{Pu}$ ratio and the final ${ }^{239} \mathrm{Pu}$ wetght fraction. Statistical precision estimates are propagated from the estimates for the individual isotopic ratios. 


\section{CALIBRATION}

Tr.e basic expression for isotopic ratios from gamma spectroscopy (Eq. 1) produces results using published fundamental constants that, in principle, can be used without recourse to standards. We have incorporated adjustable calibration constants into these ratios to adjust for brancining ratio errors and biases in peak-area and relative efficrency algorithms. By calibration we mean the adjustment of these conctants to give the best agreement with measurements on "known standards."

Obtaining knowil standards is more difficult than it may seem. There are problems with even the National Bureau of Standards reference material. 4 The determination of ${ }^{241}$ Am concentrations in many of the samples available to us is not as precise as desired. We find that the best ${ }^{241}$ Am values, for our purposes, are obtained by allowing the ${ }^{24 l} \mathrm{Am}$ to grow into a high ${ }^{24 \mathrm{I}_{\mathrm{Pu}}}$ content sample and calculating the ${ }^{241}$ Am knowing the half-lives and chemical separation date.

The constants are adjusted by comparing the measured isotopic ratios determined from repeated high-precision, long runs with those ratios determined from the best appropriate chemical techniques. Such calibration results are shown in Fig. 2. Here a wide $r$ ange of sample sizes and types were counted ranging from several hunclred grams to $0.25 \mathrm{~g}$. The $240 \mathrm{Pu}$ content. ranged from $6 \mathrm{to} 1 \mathrm{R}^{\prime \prime}$. The best values for the calibration constants were used to recimpute the isotopics. It is the recomputed isotopics, after adjustment of the calibration constant.s, ihat are displayed in Fig. 2. The fact that the mean val.as are noi 1.0 illustrates the difficulty in making these adjustments for such a wide range of isotopics, especially for ${ }^{240} \mathrm{Pu}$ which has three terms in its ${ }^{240} \mathrm{Pu}{ }^{241}$ Pu-ratio expression.

Over a wide rance of sumple sizes, configurations, and isotopic composition, the isotopics measured hy ganma-ray spectroscopy show essentially no bias. Pocr alpha spectrometer determinations of ${ }^{2.38} \mathrm{pu}$ may contribute to the: relatively poor precision observed in rig. ? for that isotope. The extent of this contribution is not known.

V. PLIITINTUM MASS MIASUREMENTS WITH (AL.ORIMITRY ANI) GAMMA-RAY SPECTROSCOPY

The isotopics calibration that produced the results in Fig. 2 was used with gamma-ray spectrnscopy medsurements of thirtecen 1000-4 samples of rast flux 
Test Facility (FFTF) $\mathrm{PuO}_{2}$ and one 500-g sample of low burn up metal. All samples were also measured in a calorimeter. The plutonium isotopic composition decermined from the gamma-ray measurement was used to determine the sample's specific power in $\mathrm{W} / \mathrm{g}$ plutonium, which was combined with the calorimeter measurement of sample power in watts to give the sample mass in grams of plutonium. ${ }^{14}$ The results for the plutonium mass are compared with the accepted values determined by destructive chemical ana?ys is for $g$ plutonium/g sample, ignition for moisture content, weighing, and mass spectrometry for isotopic composition.

This combination technique is not new, having been in use at Mound Laboratory $y^{18}$ and Rockwell-tianfor ${ }^{3}$ for some tilie. This is, however, the first application of this powerful combination of NDA teciniques at Los Alamos.

The $\mathrm{PuO}_{2}$ had nominal isotopic composition of $0.06 \% 238 \mathrm{Pu}, 86.6 \%$ ${ }^{239} \mathrm{Pu}, 11.8 \%{ }^{240} \mathrm{Pu}, 1.3 \%{ }^{241} \mathrm{Pu}, 0.2 \%{ }^{242} \mathrm{Pu}$, and $600 \mathrm{ppm}{ }^{241} \mathrm{Am}$. The low burnup metal's isotopic as determined by mass spectrometry was $0.04:$; ${ }^{238} \mathrm{Pu}, 93.8 \%{ }^{239} \mathrm{Pu}, 5.9 \% 240 \mathrm{Pu}, 0.27 \% 241_{\mathrm{Pu}}, 0.03 \% 242 \mathrm{Pu}$, and 360 ppın americum (radiochemically measured).

In Table I the 4-h gamma-ray isotopic measurements are presented as ratios to the mass spectrometry values. Agreement is seen to be excellent for the major plutonium isotopes with the exception of ${ }^{238} \mathrm{Pu}$. Here, ${ }^{238} \mathrm{U}$ contamination is always a problem for mass spectrometry and can produce large errors at these relatively low concentrations $(0.05$ to $0.07 \%)$. The gamma spectroscopy results are inore reliable than mass spectrometry measurements of ${ }^{238} \mathrm{Pu}$ in general. The bias in the ${ }^{242} \mathrm{Pu}$ results arises from the isotopic correlation technique used. Over a narrow burnup range the bias may be substantially reduced by choosing a different correlation. In any case, this bias is rot significant for total plutonium determination because ${ }^{242} \mathrm{Pu}$ contributes negligibly to the plutonium specific power.

The relative?y large bias and standard deviation for ${ }^{241} \mathrm{Am}$ is caused by the poor siatistical precision of the gamna spectroscopy measurement at these lower americium levels ( 300 to $700 \mathrm{ppm}$ ) and the imprecision of the radioanalytical techniques used to determine the "standard" values. For these low americium content samples, the americium contributos only a minor porition (1 to $2 \%$ ) of the sample power. The gamma-ray measurement precision improves for higher americium concentrations, which can contribute significantly to the sample power. 
The gamma-spectrometer isotopics were used to interpret a calorimetry measurement on each sample. The calorimetry-garma spectroscopy comparison with chemical analys is is shown graphically in Fig. 3. The observed precision of $0.6 \%$ for the plutonium mass determination comparison in Fig. 3 also contains a contribution from the precision of the weighing and destructive chemical analysis techniques used to determine the "accepted" chemical analys is values. Experience indicates that this contribution may be 0.1 to $0.2 \% 18$

In Table II we sumarize some of the precisions that have been observed on measurements of three different sample types. The first entries for FFTF oxide summarize the measurements already discussed. The other two entries (reactor-grade oxide and :ow-burnup oxide) summarize the res'slts of repeated measurements of the specific power from gamma-ray isotopics. These two samples did not have enough saniple mass (a few grams) or a precise eriough plutonium mass value to enable them to be measured in our calorimeter. Larger samples than these would give puorer precision tecause of the increased effect of the compton continuum in the 100 to $200-\mathrm{keV}$ region arising from the 300 to 400-keV plutonium gamma rays.

The Table II entries illustrate iiow the precisior of the specific power can vary, especially as a function of the isotopic composition. ior low americium :amples the uncertainty in ihie 940 pu isutopic dominates the predicted precision. As the americium content increases, the ${ }^{240} \mathrm{Pu}$ power contribution becomes less important and results in inproved overall precisior.

\section{APPLICATION TO URANIUM-PLUTONIUM MIXED OXIDES AND MATERIALS WITH FISSION PRODUCT CONTENT}

We have made measuren:ment.s on uranium-plutonium mixed oxides to determine if the ${ }^{2.35} \mathrm{U}$ gamma rays at $16.3 .4,202.1$, and $205.3 \mathrm{kcV}$ interfere with the $240 \mathrm{Pu}{ }^{24} \mathrm{I}_{\mathrm{Pu}}$ measurement at $150.2 / 164.6 \mathrm{keV}$ and the ${ }^{239} \mathrm{Pu}^{241} \mathrm{Pu}$ ratio measured at $203.51208 .0 \mathrm{keV}$. With proper sclection of regions of interest one $\mathrm{c}$ an perform unbiased measurements of the ${ }^{240} \mathrm{Pu} /{ }^{241} \mathrm{Pu}$ and

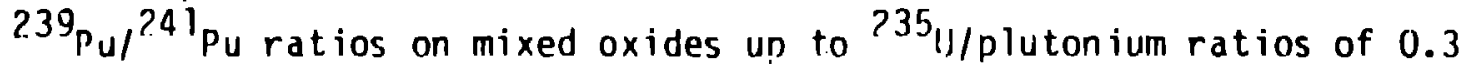
for the ${ }^{239} \mathrm{Pu} /{ }^{241} \mathrm{Pu}$ ratio and 3.0 for the ${ }^{240} \mathrm{Pu} /{ }^{241} \mathrm{Pu}$ ratio. For comparison we note that mixed cxides with natural uranium:plutonium ratios of 
3 or 4 to 1 (typical of US fast breeder reactor fuel) will give a

235 U/plutonium ratio in the range of 0.02 to 0.03 , well within the range of this technique.

Additional measurements have been made on plutonium samples plus added ${ }^{137} \mathrm{Cs}$ to mockup fission product artivity. The measurement of plutonium isotopic ratios in the 100 to 200-keV region suffers from the increased compton continuum arising from 600 to $800-\mathrm{keV}$ fission-product gamma rays. The degredation is enough to make ${ }^{238} \mathrm{Pu} /{ }^{241} \mathrm{Pu}$ and ${ }^{240} \mathrm{Pu} /{ }^{241} \mathrm{Pu}$ measurements on low burnup plutonium $(\sim \bar{\sigma} \% 240 \mathrm{Pu})$ not meaningful above fission product concentrations of abcut $10 \mu \mathrm{Ci} / \mathrm{g} \mathrm{Pu}$. For higher burnup plutonium these measurements can tolerate fission product concentrations of around $20 \mu \mathrm{Ci} / \mathrm{J} \mathrm{Pu}$. 


\section{REFERENCES}

1. J. L. Parker and T. D. Reilly, "Plutcnium Isotopic Determination by Gamma-Ray Spectroscopy," in "Nuclear Analys is Research and Develcpment Program Status Report," Jan. - April 1974, Los Alamos National Labcratory' report LA-5675-PR (August i974).

2. J. G. Fleissner, J. F. Lemming, and J. Y. Jarvis, "Study of a TwoDetector Method for Measuring Plutonium Isotopics," Proc. Am. Nucl. Soc. Conf. on Measurement Technology for Safeguards and Materials Control, Y.iawah Is land, S.C., November 26-29, 1979.

3. R. A. Hariliton, Atlantic Richfield Hanford Co., Letter and enclosures to W. W. Rodenburg, Mound Laboratory (February 18, 1977).

4. H. Ottmar and E. Eberle, "Determination of Plutonium Isotopic Composition by Ganima Spectrometry: Results from Interlaboratory Coniparison Measurements Or zanizer by ESARDA," lst Annual ESARDA Symposium on Safeguards and Nuclear Materials Management, April 10, 1979. See also INMM Journal, VIII (1979).

5. R. Gunnink, J. B. Niday, and P. D. Siemens, "A System for Plutonium Analys is by Camma-Ray Spectrometry, Part I: Techniques for Analys is of Solutions," Lawrence Livermore Laboratory report UCRL-51577 (Apri] 1974).

6. R. Gunnink and J. E. Evans, "In-Line Measurement of Total and Isotopic Plutonium Concentrations by Gamma-Ray Spectrometry, "Lawrence Livermore Laioratory report UCRL-52220 (1977).

7. R. Gunnink, A. L. Prindle, J. B. Niday, A. L. VanLehn, and Y. Asakura, "TASTEX Gamma Spectrometer System for asuring Isotopic and Total Plutonium Concentrations in Solutions," Jcurnal INPM, VIII (1979), p. 4?9. See also Lawrence Livermore Laboratory report UCRL-82335 (1979).

8. L. R. Co'nder, S. -T. Hsue, S. S. Johnson, J. L. Parker, P. A. Russo, ․ K. Sprinkle, Y. Asakura, T. Fukuda, and I. Kondo, "Gamma-Ray NDA Nssay System for Total Plutonium and Isotopics in Plutonium Product Solutions," Proc. ANS Topical Conf. on Measurement Technology for Safeguards and Materials Control, Kiawah Island, S.C., Novemier 26-29, 1979.

9. H. Umezawa, T. Suzuki, and S. Ichikawa, "Gamma-Ray Spectrometic Determination of Isotopic Ratics of Plutonium," J. Nucl. Sci. Technology, 13, $327(1976)$.

10. T. N. Dragnev, "Intrinsic Seif-Calibration of Non-Destructive Ganma Sperirometric Measurements. Determination of $U, \mathrm{Pu}$, and $241_{\text {Am I I ntop- }}$ i: Ralivi," . Radioanal. Chem., 36, 491 (1977).

11. T. Drainnay and K. Jcharf, "Non-Destructive Gamma Spectrometry Measurement of :38pu/?aOpu and Pu/?40pu Ratios," Int. J. Appl. Radiat. lsot.., 26, $125(1975)$. 
12. T. N. Dragnev and B. F. Damjanov, "Methods for Precise Absolute GammaSpectrometic Measurements of Uranicm and Plutonium Isotopic Ratios," Nuclear jafequards Technology 1978, Vol. 1, IAEA, Vienna, Austria, Tा979), p. 739 .

13. T. R. Reilly, D. D'Adamo, I. Nessler, and M. Cuypers, "Gamma-Ray Spectrometric Determination of Plutonium Isotopic Composition, "Nuclear Safeguards Technology 1979, 1, IAEA, Vienna, Austria (1979), p. 727.

14. "American National Standard Calibration Techniques for the Calor"metric Assay of Plutonium-Bearing Solins Applied to Nuclear Materials Control," American Natiunal Standards Institute N15.22-1975 (June 1975).

15. R. Gunnink, J. E. Evans, and A. L. Prindle, "A Reevaluation of the Gamma-Ray Eriergies and Atsolute Branching Intensities of 237U, $238, ? 39,240,241 \mathrm{Pu}$, and $241 \mathrm{Am}, "$ Lawrence Liverm re Laboratory report UCRL- 52.139 (October 1976).

16. R. H. Auqustson arid T. D. Reilly, "Fundamentals of Passive Nondestructive Assay of Fissioriahle Materials," Los Alamos ivational Laboratory report LA-5651-M (September 1974).

17. M. S. Krick. "240pu-fffective Mass Formula for Coincidence Countina of Plistonium with SR Elecironics, in "Nuclear Safeguards Research and Develorment Program Status Report," May-August 1977, Los Alamos National l.aboratory repor: LA-7030-PR (March 1978).

18. W. W. Rodenbura, "An Evalisation of the Use of Calorimetry for ShipperReceiver Measurements of Plutonium, "Monsanto Research Corporation. Mound Laboratory report MLM-2518 (1978). 


\section{FIGURE CAPTIONS}

Fig. 1 Typical relative efficiency curves for two sample sizes using a $200-m n^{2} \times 10-m m$ deep planar detector. Sol id circles are goints from $239 \mathrm{pu}$. Triangles are points from $241 \mathrm{pu}$ and

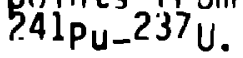

Fig. ?

Comparison of measured plutonium isotopic with mass spectrometry.

Fig. 3

Total nlutonium determination by combination of calorimetry and gamma spectrisscopy compared to conventional chemistry techniques. Error bars are predicted uncertainties arising from gamma-ray isotopic determination. 
TAELE I

PLUTONIUM ISOTOPIC. BY GAMMA-RAY SPECTROSCOPY

Sample

$\underline{238 p u}$

Ratio: $\frac{\text { Gamma Spoctroscony }(4 \mathrm{~h})}{\text { Mass Spectrjscopy }}$

Plutonium 0xide:

LA0134C]

I.AO134C'

LAO 34 C 3

LA0134C 4

I.A0134C 5

LAO134C6

L.A0134C.8

LA0135C.B

LA0145C. 3

LAO $148 C 3$

LAO153C?

LAO154C 3

LAO150C. 3

$0.8778 \quad 0.0995$

0.8486

I. 0022

1.0590

0.8850

0.0948

1.0000

0.8810

$0.999 ?$

1.0042

$\begin{array}{lll}0.8292 & 0.9975 & 1.0169\end{array}$

0.8746

0.9972

1.0151

0.9052

0.9987

1.0074

0.9729

0.3945

1.0398

0.8990

0.9965

1.0243

0.7331

1.0077

0.9402

0.8149

0.9955

1.0324

0.9152

1.001 ?

0.9951

0.9964

1.0231

$241 \mathrm{pu}$

$\underline{242 p_{u}} \quad \underline{241_{\text {AnI }}}$

0.9587

0.9934

0.9986

1.171

0.994

0.9954

1.138

0.932

0.9965

0.9946

0.9943

1.159

1.036

0.9996

1.003

$1.184 \quad$ l. .989

$1.187 \quad 1.037$

0.9998

1.173

1.117

0.9945

1.129

1.047

1.0122

1.169

0.843

1.0071

1.200

1.239

0.9991

0.994 ?

1.091

1.239

$1.229 \quad 1.221$

$1.724 \quad 1.031$

Lon' Burnup Mietal: Jn013?4

$0.3437 \star \star \quad 1.0010 \quad 0.9844$

0.4955

$0.6839 x+1.116$

mean (hias)

$0.876 ?$

0.9990

1.0056

0.7982

1. 171

1. (0) ()

observed

$0.06 ?$

0.0034

0.075

0.00 .51

0.0 .37

0.116

*americum deterrined by radioanalytical techniaues

* nmitted from average. 
TABLE II

PRECISION OF DETERMINAT'ON OF SPECIFIC POWER

USING GAMMA-RAY SPECTROSCOPY

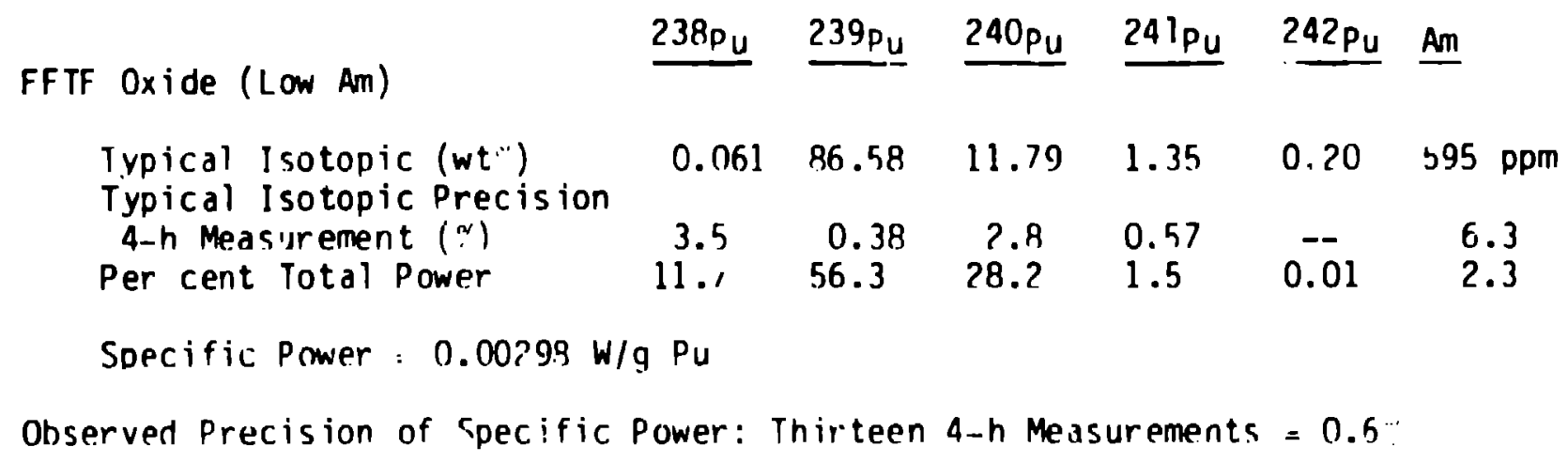

Reactor-Grade Oxide (Hiqh, Am)

Typical Isotopic (wt".)

Typical Isotopic. Precis ion

7.4-h Measurement ( $(\because)$

0.74

84.10

17.36

2.77

$0.5316000 \mathrm{ppm}$

Per cent Total Power

0.70

0.24

1.70

0.54

$14.6 \quad 1.6$

0.01

0.15

23.6

i.8.

1.6

Sperific. Power - $0.00577 \mathrm{~W} / \mathrm{g} \mathrm{ru}$

Observed Precision of Specific Power: Nine 7.4-h Measurements $=0.15 \mathrm{~m}$

\footnotetext{
I ow-Burnup Oxide (1. ow Am)

\begin{tabular}{|c|c|c|c|c|c|c|}
\hline Typiral Isotopir. (wt".') & 0.014 & 93.34 & 6.30 & (1. $3 \%$ & 0.026 & $189 \mathrm{ppm}$ \\
\hline 5.9-h Modsureinent ("i) & 5.0 & 0.11 & ?. & 0.11 & $\cdots$ & !). \\
\hline Per cent Total Power & 3.3 & $16 . !$ & 18.7 & 0.46 & 0.001 & 1.07 \\
\hline
\end{tabular}

Sprecifir lower - (..00)i3! will Pu

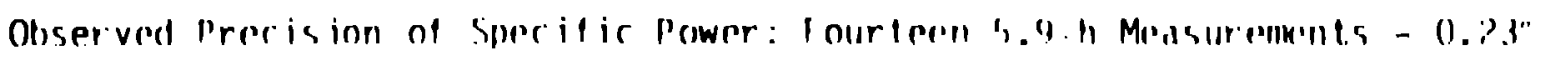




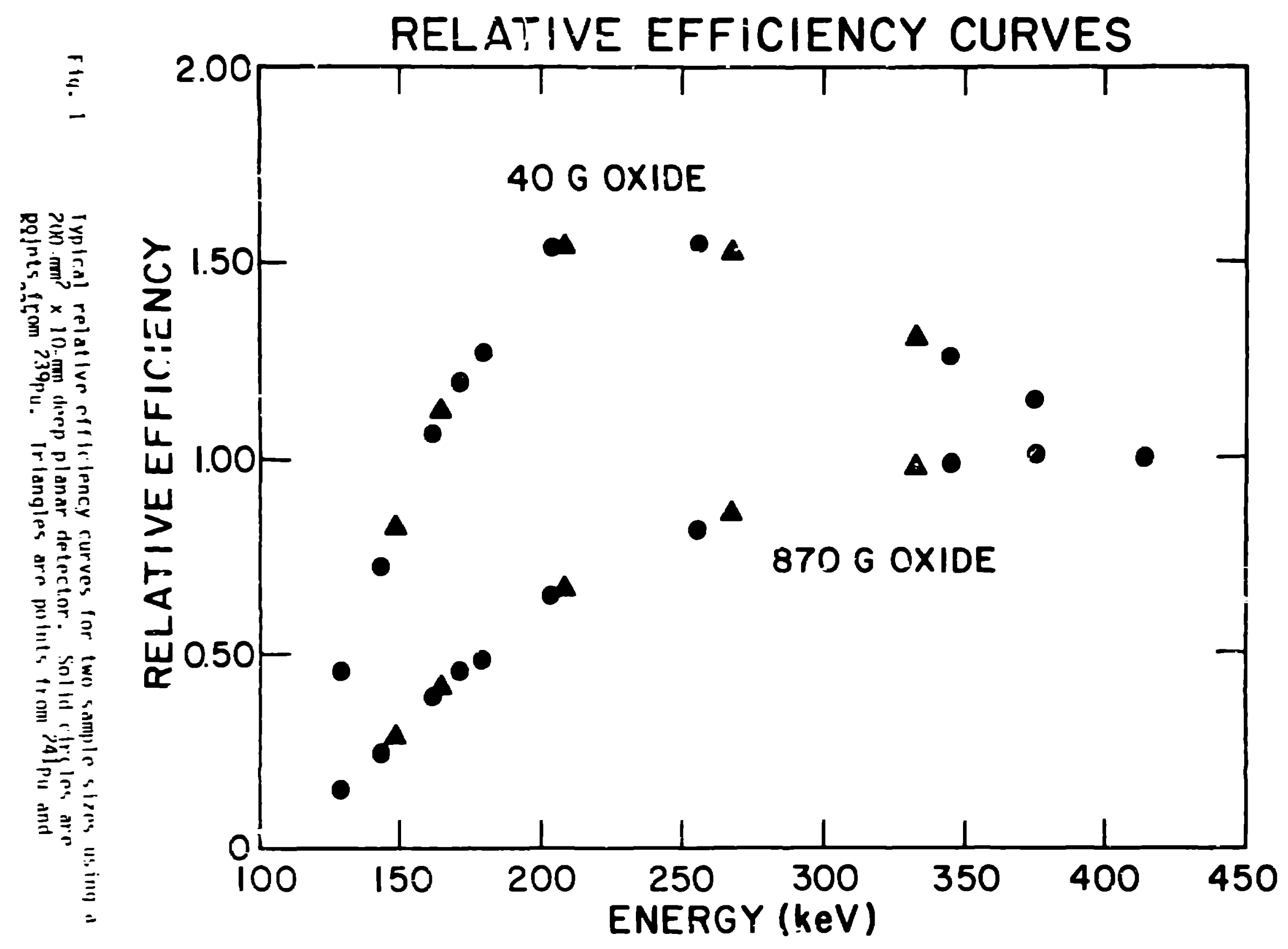




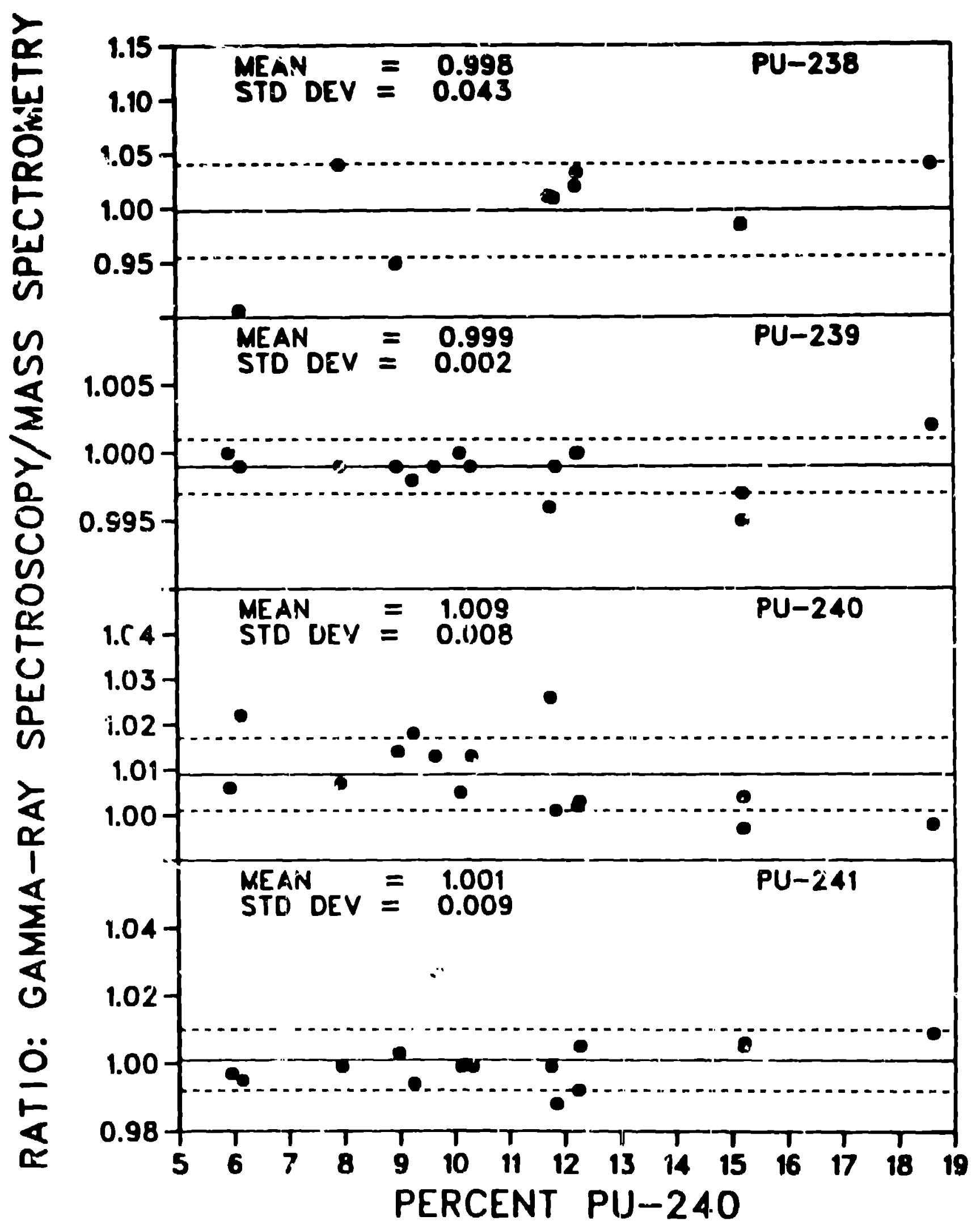

rig.? Compartson of mensured plutonfum isotopte with mass spectronetry. 


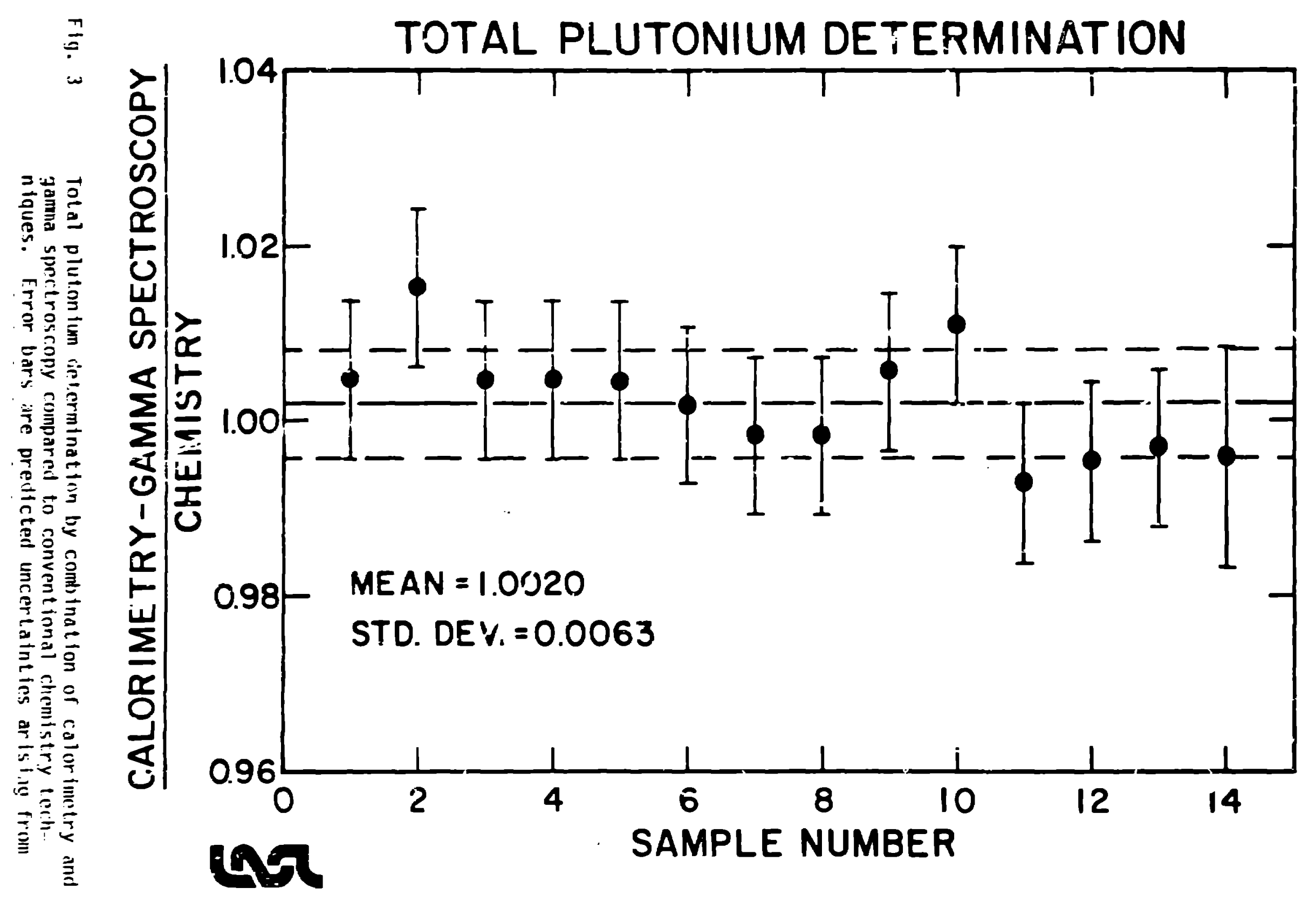

